\title{
Passability of Potamodromous Species through a Fish Lift at a Large Hydropower Plant (Touvedo, Portugal)
}

\author{
Daniel Mameri ${ }^{1}$, Rui Rivaes ${ }^{1}{ }^{1}$, João M. Oliveira ${ }^{1,2}$, João Pádua ${ }^{3}$, Maria T. Ferreira ${ }^{1}$ and \\ José M. Santos ${ }^{1, * \mathbb{D}}$ \\ 1 Forest Research Centre (CEF), School of Agriculture, University of Lisbon, Tapada da Ajuda, \\ 1349-017 Lisboa, Portugal; dmameri@isa.ulisboa.pt (D.M.); ruirivaes@isa.ulisboa.pt (R.R.); \\ joliveira@isa.ulisboa.pt (J.M.O.); terferreira@isa.ulisboa.pt (M.T.F.) \\ 2 Centre for Ecology, Evolution and Environmental Changes (cE3c), Faculty of Sciences, University of Lisbon, \\ 1749-016 Lisboa, Portugal \\ 3 EDP Labelec-Estudos, Desenvolvimento e Actividades Laboratoriais, S.A., Rua Cidade de Goa, 4, \\ 2685-038 Sacavém, Portugal; Joao.Padua@edp.com \\ * Correspondence: jmsantos@isa.ulisboa.pt; Tel.: +351-213-653-489
}

Received: 11 October 2019; Accepted: 18 December 2019; Published: 24 December 2019

\begin{abstract}
River fragmentation by large hydropower plants (LHP) has been recognized as a major threat for potamodromous fish. Fishways have thus been built to partially restore connectivity, with fish lifts representing the most cost-effective type at high head obstacles. This study assessed the effectiveness with which a fish lift in a LHP on the River Lima (Touvedo, Portugal), allows potamodromous fish-Iberian barbel (Luciobarbus bocagei), Northern straight-mouth nase (Pseudochondrostoma duriense) and brown trout (Salmo trutta fario)- to migrate upstream. Most fish (79.5\%) used the lift between summer and early-fall. Water temperature was the most significant predictor of both cyprinids' movements, whereas mean daily flow was more important for trout. Movements differed according to peak-flow magnitude: nase $(67.8 \%)$ made broader use of the lift in the absence of turbined flow, whereas a relevant proportion of barbel $(44.8 \%)$ and trout $(44.2 \%)$ passed when the powerhouse was operating at half $\left(50 \mathrm{~m}^{3} \mathrm{~s}^{-1}\right)$ and full-load $\left(100 \mathrm{~m}^{3} \mathrm{~s}^{-1}\right)$, respectively. Size-selectivity found for barbel and trout could reflect electrofishing bias towards smaller sizes. The comparison of daily abundance patterns in the river with fish lift records allowed the assessment of the lift's efficacy, although biological requirements of target species must be considered. Results are discussed in the context of management strategies, with recommendations for future studies.
\end{abstract}

Keywords: potamodromous fish; migration; lift; hydropower; species management

\section{Introduction}

Rivers are currently one of the most threatened ecosystems in the world [1,2], with flow regulation and longitudinal fragmentation by dams and weirs being among the main causes of environmental degradation and reduction of available habitat for freshwater fauna [3-5]. Large hydropower plants (LHP) are particularly harmful for fish populations, not only by causing the blockage to their movements, but also by increasing the risk of fish stranding, drifting and dewatering of spawning grounds caused by flow variations, as results of peak-operations in response to energy demands [6-9]. In fact, a myriad of studies have reported significant declines or extinctions of many fish affected by LHP [10-13]. Particularly impacted are potamodromous species, i.e., freshwater species that seasonally undergo upstream migrations along the river, for the purpose of finding suitable habitats for reproduction, which are needed to complete their life-cycles [14-16]. A significant amount of research has therefore been carried out with the goal of restoring longitudinal connectivity in an upstream direction $[15,17]$. In this 
context, the development of fishways to transpose barriers stood up as a hydraulic structural solution which facilitates fish movements past the barriers, while partially restoring river connectivity [18-20].

From the different fishway types that have been constructed worldwide to address upstream migration of fish [18,21], fish lifts are the most used and cost-effective at high dams (>15 m; [22]), from the economic and biologic point of view [23,24]. A fish lift consists of a mechanical system which is located at the foot of an obstruction, which attracts (by a guiding flow) the fish into a cage with an inscale (non-return device), raising it and then emptying it in the reservoir upstream, transporting fish over the barrier (for schemes see [18,25]). Although much less studies on fish lifts are available when compared to other fishways, such as pool-type or nature-like facilities $[17,26]$, these structures have nonetheless been monitored in different regions and targeted different fish species [27]. In Europe, fish lift studies have mostly addressed salmonids [23,24,28] and eels [29], but also cyprinids $[30,31]$. However, most assessments were performed without considering the abundance and size-structure of fish species downstream the dam (often costly due to the human resources and equipment involved) that potentially constitute the migrant population to use the fish lift (but see Discussion below). Such information, in addition to seasonal and daily patterns of fish migration and associated environmental triggers [32], is fundamental to address fish lift selectivity and efficacy, and may be useful to support management decisions.

Studies of the effectiveness of fishways on LHP often focus on high-value economic and recreational species, namely diadromous and salmonids [33,34], whereas studies on potamodromous fish have often been neglected $[17,26]$. These species, however, are well represented in riverine fish assemblages, particularly in Iberia [9,35,36] and free instream movement is crucial for their survival [37]. Moreover, this is particularly important as potamodromous fish are key components of the lower and middle reaches of temperate rivers [38] and sensitive to river regulation and longitudinal fragmentation [16]. Within the fish community present in the study area, the cyprinids Iberian barbel Luciobarbus bocagei (Steindachner, 1864) (hereafter barbel) and Northern straight-mouth nase Pseudochondrostoma duriense (Coelho, 1985) (hereafter nase), and the salmonid brown trout Salmo trutta fario (Linnaeus, 1758) (hereafter trout) are amongst the most abundant species in northern Iberian rivers [39] and were therefore the focus of this study.

The main goal of this study was therefore to assess the effectiveness with which a fish lift in a large hydropower plant on the River Lima (Portugal), allows potamodromous fish to migrate upstream. For this, we assessed the seasonal and daily use of the lift by the fish population and compared it with (1) the environmental factors that are known to be associated with the triggering of the fish upstream migration; (2) the peak-flow magnitudes at the power plant (0,50 and $100 \mathrm{~m}^{3} \mathrm{~s}^{-1}$, see Study Area); and (3) the size structure (to infer selectivity) and abundance (to calculate a ratio of effectiveness) of the fish population downstream.

We predict that (i) fish counts through the lift would vary between the different months for all three species following patterns outlined in the literature, i.e., cyprinid species movements should mainly occur during the reproductive season, i.e., summer [40,41], and further extending to early fall when species start to search for winter, feeding or thermal refuges [15,42] (with regard to the trout, movements are predicted as well to occur in the reproductive season, in this case, between late fall and early-winter [43]); (ii) daily activity of the studied species would not show marked diurnal/nocturnal preferences due to the absence of natural predators in the River Lima [16,44], which should not restrict movements to take place preferentially during the night, when survival is expected to be maximum [26]; (iii) water temperature and flow, two of the most important environmental factors responsible for triggering migration [35,45], would be the most significant ones for the target species; (iv) large-sized and faster-flowing species would be better able to cope with higher peak-flow magnitudes (50 and $100 \mathrm{~m}^{3} \mathrm{~s}^{-1}$ ) than smaller ones, and hence expected to use the lift during such conditions; and (v) selectivity should be low, although the presence of larger individuals in the lift when compared to the downstream river segment, would be expected to occur as a result of upstream migration of adults to spawning sites [41]. 


\section{Materials and Methods}

\subsection{Study Area}

The River Lima runs for $135 \mathrm{~km}$ in the north-west part of Iberian Peninsula, being shared by Spain and Portugal (Figure 1). It runs on a NE-SW direction and is characterized by a relatively high run-off, as a result of a mean annual rainfall of about $2000 \mathrm{~mm}$. Geology is mainly granitic and the topography consists of a series of steep and narrow valleys in the upper reaches, contrasting with the lower reaches, with milder gradients and wider valleys dominated by alluvial materials.
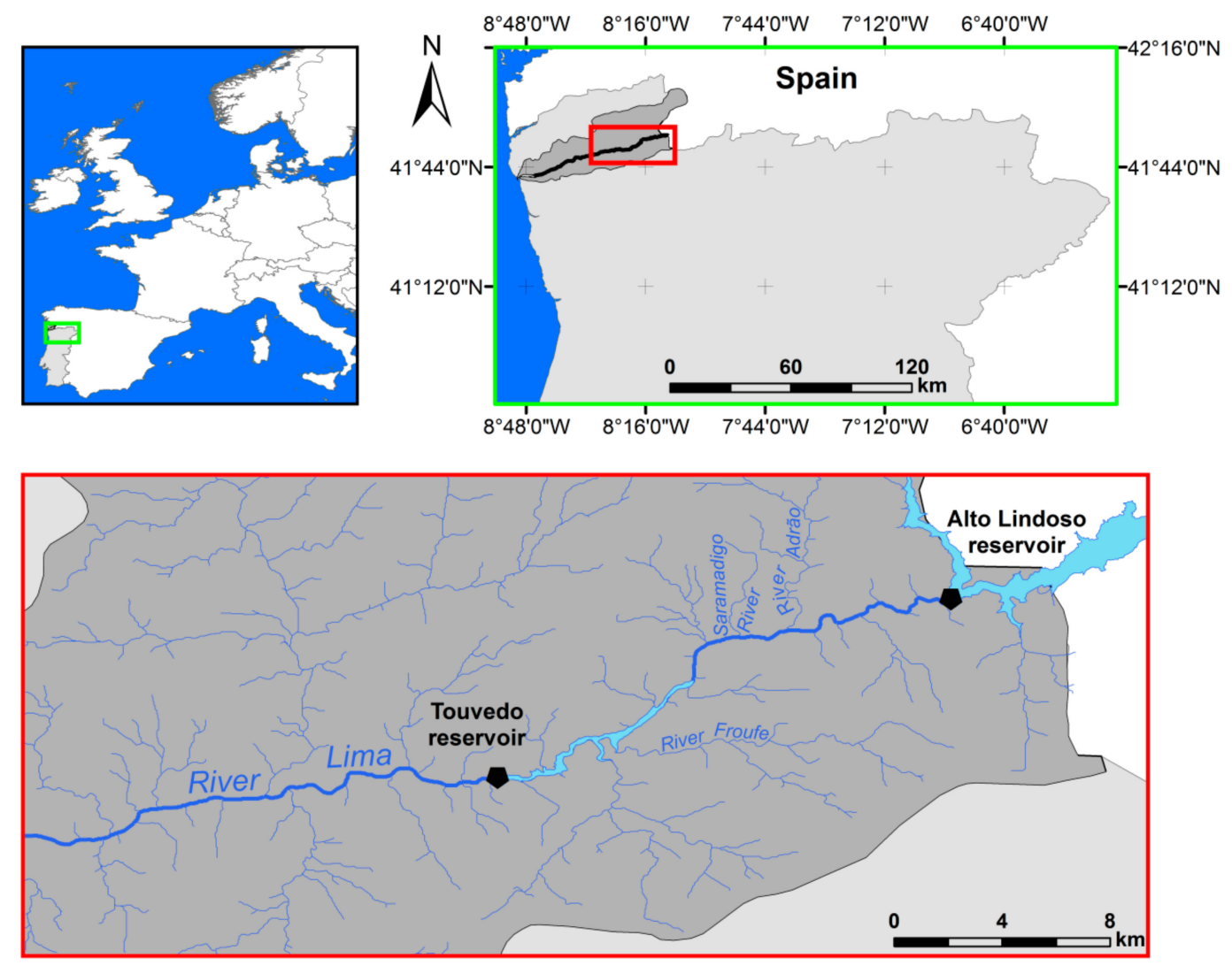

Figure 1. Map of the study area in the River Lima, North Portugal. The black pentagons refer to the dam locations.

The Touvedo LHP stands at $47 \mathrm{~km}$ from the river mouth and is the first large instream barrier to upstream fish migration. It is $42 \mathrm{~m}$ high and it serves as a tailwater reservoir for the high flows released by the Alto Lindoso Dam, located $16.5 \mathrm{~km}$ upstream $\left(250 \mathrm{~m}^{3} \mathrm{~s}^{-1}\right.$ at full operation), by temporarily storing them, and then returning them to the river, with values not higher than $100 \mathrm{~m}^{3} \mathrm{~s}^{-1}$. The dam is equipped with a 22-MW Kaplan turbine and three spillway gates, with a maximum discharge of $3200 \mathrm{~m}^{3} \mathrm{~s}^{-1}$ when the reservoir reaches the run-off storage limit. Mean number of spillway discharge events is 32/year, which mainly occur (c. $80 \%$ ) from mid-autumn to early spring [44]. The Touvedo LHP works under three peak-flow magnitudes: (i) $0 \mathrm{~m}^{3} \mathrm{~s}^{-1}$, turbine shutdown (i.e., powerhouse off), which is compensated by a $5.5 \mathrm{~m}^{3} \mathrm{~s}^{-1}$ constant ecological flow (a minimum of $4.0 \mathrm{~m}^{3} \mathrm{~s}^{-1}+1.5 \mathrm{~m}^{3} \mathrm{~s}^{-1}$ from the fish lift) to ensure the connectivity of the different habitats and movements of species downstream; (ii) $50 \mathrm{~m}^{3} \mathrm{~s}^{-1}$, half-load operation; and (iii) $100 \mathrm{~m}^{3} \mathrm{~s}^{-1}$, full-load operation.

A network of spawning, feeding and refuge habitats is available for fish upstream the Touvedo dam. These are mainly located in the Rivers Adrão, Froufe and Saramadigo, which have no man-made obstacles (i.e., all free-flowing) and also no sources of pollution across their watersheds [9]. 
The dam features a fish lift (2.1 $\mathrm{m}$ long, $1.3 \mathrm{~m}$ wide and $2.9 \mathrm{~m}$ high) which is located on the left bank. It has 3 entrances (two placed above the turbine gates and another one displaced $20 \mathrm{~m}$ downstream, to take advantage of the turbined flow) and was initially designed to improve diadromous species movements, such as Atlantic salmon Salmo salar and sea trout Salmo trutta trutta. A maximum attraction flow of $4.5 \mathrm{~m}^{3} \mathrm{~s}^{-1}$ is released to promote attraction towards the entrances, which have a mean water velocity varying between 0.21 and $0.55 \mathrm{~m} \mathrm{~s}^{-1}$ (turbine shutdown, powerhouse off) and between 0.68 and $0.91 \mathrm{~m} \mathrm{~s}^{-1}$ (turbine operating, powerhouse on), as previously measured with a SonTek FlowTracker Handheld ADV (model number P4267, Qualitas Instruments Ltd., Madrid, Spain, 2012) at nine points across their width [44]. Inside the attraction circuit, the fish move towards the trapping cage, which is set to raise and empty every $4-h$.

\subsection{Fish Passage through the Lift}

To account for seasonal variations in migration patterns, monitoring of fish passage through the lift was made on a monthly basis, from March 2013 until February 2014. Continuous data was acquired through an automatic video-recording system, which included a video camera (Bosch, mod. MR700, Gerlingen, Germany) placed on the top of the fish lift (allowing the collection of trapping cage images during the final period of the cage ascent) and a video recorder (Bosch, mod. LTC455). Target species (barbel, nase and trout) were the most frequent and abundant potamodromous fish species previously recorded in the catchment $[30,44]$. Following this approach, no fish handling was required, as opposed to other monitoring techniques (e.g., mark-recapture or radio telemetry), thus avoiding causing injury or stress to the fish. The camera was installed on the upper part of the fish lift in order to acquire images of the lift cage during its final period of ascension. The trapping cage was sealed with $20 \times 20 \mathrm{~cm}$ white quadrats to obtain clearer images for identification and estimates of fish lengths [29]. Collected data included: the timing of fish passage (day and hour), the number of fish per cycle, the identification of each fish to the species level and the estimated total length of individuals (TL, to the nearest $\mathrm{cm}$ ). For further details on the video-recording system, see [29].

To determine the role of environmental variables on fish movements, six potential predictors were recorded: (1) water temperature, recorded on an hourly basis by a Vemco Minilog-II probe placed in the downstream river segment; (2) mean daily flow, defined as the amount of flow through the turbine, spillway or ecological flow provided by the dam reports on an hourly basis; (3) daily flow fluctuation, i.e., the standard deviation of hourly flows—-turbined, spillway or ecological—provided by the dam reports; (4) mean daily rainfall, provided by a nearby weather station (code 03F/01G, managed by the Portuguese Institute for Sea and Atmosphere, I.P.), located $17 \mathrm{~km}$ downstream from the Touvedo dam; (5) accumulated rainfall, obtained by combination of the mean daily rainfall that occurred on the three preceding days (as we predicted that fish would move upstream a few days earlier in response to accumulated rainfall; (6) photoperiod, as the time of civil twilight, i.e., the length (in hours) of the daytime period, obtained at http://zenite.nu/ (accessed June 2018); and (7) the proportion of illumination of the moon, based on the ephemeris available at http://www.rodur.ago.net/en/ (accessed June 2018), obtained by dividing the lunar cycle into four phases.

\subsection{Fish Catches Downstream}

To obtain a measure of fish lift efficacy, surveys $(n=9)$ were performed once every month (unable to sample on March 2013 and January-February 2014, due to adverse weather conditions) in a river segment (total length: $340 \mathrm{~m}$ ) located immediately downstream the dam, by using a combined wadable and boat electrofishing scheme (DC, 300-700 V, SAREL model WFC7-HV, Electracatch International, Wolverhampton, UK) to obtain the most reliable picture of fish abundance (unit effort $=1$ fishing day-4h of effective sampling-along with ratios of fish-lift records to downstream catches; for further details on the sampling procedure, see [29]). Fish were then identified and measured for TL (nearest $\mathrm{cm}$ ); native specimens were then returned to the river alive, whereas non-natives were sacrificed in accordance with Portuguese legislation. Fish surveys were not performed in March 2013 
and January-February 2014 due to adverse weather conditions (high flow events) that prevented secure access to the river.

\subsection{Data Analyses}

Monthly fish counts recorded in the lift were initially plotted on a line chart to examine seasonal activity and search for migration periods. Next, to search for eventual daily patterns of passage through the lift, two periods were considered: 06:00-18:00 h (day) and 18:00-06:00 h (night) [41]. For both data, the chi-square test of goodness of fit was conducted to account for differences in the relative abundance of fish passing through the lift in each month and between day and night periods, respectively.

The relative influence of environmental variables on the fish counts in the lift was also evaluated through generalized linear models (GLM) following a Poisson distribution. For this purpose, a forward stepwise approach was conducted, based on the Akaike Information Criterion (AIC) for each fitted model, selecting only the variables leading to the most adequate model (i.e., lowest AIC). In each model, variable significance was set at $\alpha=0.05$. To improve data distribution, we applied a $\log (x+1)$ transformation to all environmental variables before fitting them into the GLM, with the exception of the proportion of illumination of the moon, which was arcsin-transformed. Durbin-Watson statistics for each model were also calculated to detect possible autocorrelation between residuals (values ranging from 1 to 2 are considered to be acceptable). To search for significant differences in species movements according to the different peak-flow magnitudes $\left(0 \mathrm{~m}^{3} \mathrm{~s}^{-1}\right.$, powerhouse off; $50 \mathrm{~m}^{3} \mathrm{~s}^{-1}$, powerhouse at half-load; $100 \mathrm{~m}^{3} \mathrm{~s}^{-1}$, powerhouse at full-load), the chi-square test of goodness of fit was employed. Size selectiveness in the fish lift was assessed by comparing the population size structure of each species recorded in the lift with the one obtained downstream the dam, using Fisher's exact test. Size-classes were partitioned in 5-cm intervals, to allow a more detailed effect of selectivity [29].

Literature has outlined the absence of a standardized procedure to evaluate fish passage efficacy [17,46], a qualitative concept consisting of checking if the fishway is capable of allowing the target species to pass. This concept differs from efficiency, which focuses on its quantitative performance, defined as the percentage of marked fish that enter and successfully negotiate the fishway out of the total fish previously marked [47]. A ratio of fish lift efficacy was therefore calculated by dividing the number of fish observed ascending the lift (number day ${ }^{-1}$ ) by the total number of fish captured below the dam (unit effort = number in 1 fishing day), being considered as a proxy of the lift's efficacy [48].

All analyses were conducted in R version 3.5.2, [49], using the packages stats (implemented in R) and MASS [50].

\section{Results}

\subsection{Seasonal Fish Counts in the Lift}

Fish counts through the lift varied significantly between the different months for all three species (barbel: $\chi^{2}=57.828, \mathrm{df}=11, p<0.001$; nase: $\chi^{2}=232.440, \mathrm{df}=11, p<0.001$; trout: $\chi^{2}=66.315, \mathrm{df}=11$, $p<0.001$ ) (Figure 2). A total of 548 barbel, 1801 nase and 63 trout were recorded passing the fish lift within the study period, with most of the fish being observed between summer and early fall (79.5\%), i.e., August and October. Among the three species, nase was the most abundant (74.7\% of the total fish counts), with the highest counts being recorded in August (699) and October (491). Barbel (22.8\%) was more abundant in October (125), while trout (2.6\%), the least abundant species, peaked a maximum of 13 individuals in both April and October. 


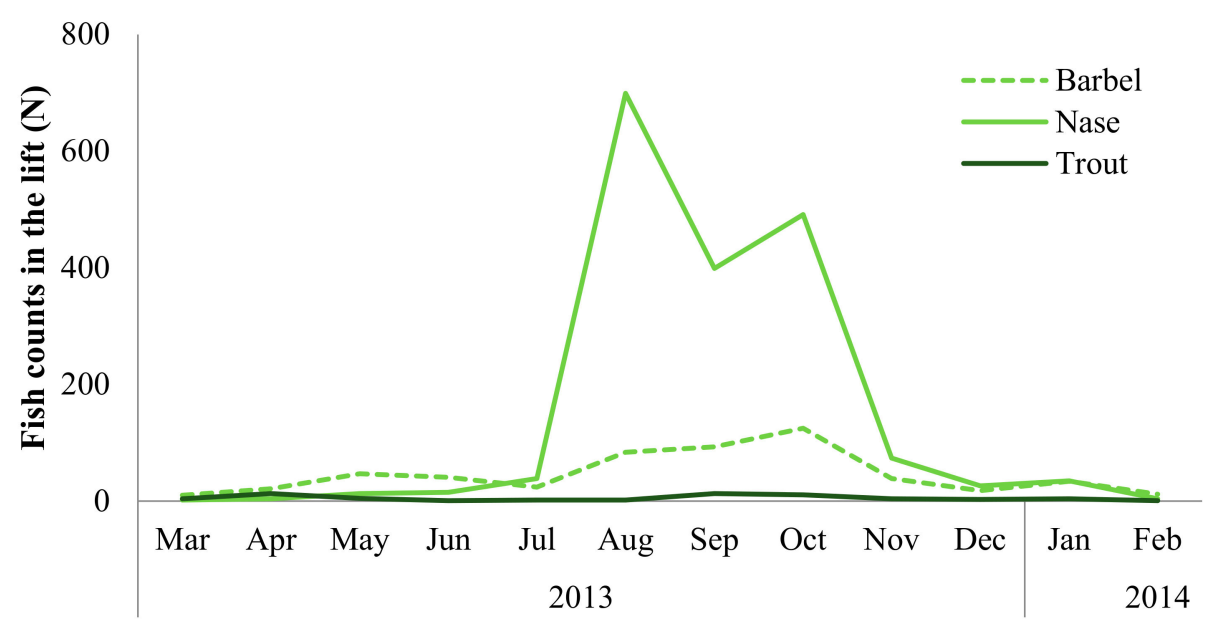

Figure 2. Fish counts for barbel (dotted green line), nase (green line) and trout (dark green line) in the fish lift, between March 2013 and February 2014.

\subsection{Daily Patterns of Fish Passage}

Fish recordings in the lift did not vary significantly with the time of day for barbel $\left(\chi^{2}=0.006\right.$, $\mathrm{df}=1, p=0.936)$, nase $\left(\chi^{2}=0.810, \mathrm{df}=1, p=0.368\right)$; and trout $\left(\chi^{2}=3.028, \mathrm{df}=1, p=0.082\right)$. Among the three species, the highest difference in percentage of fish passing between two periods belonged to trout $(58.7 \%$ of the fish counts recorded during the night period) (Figure 3$)$.

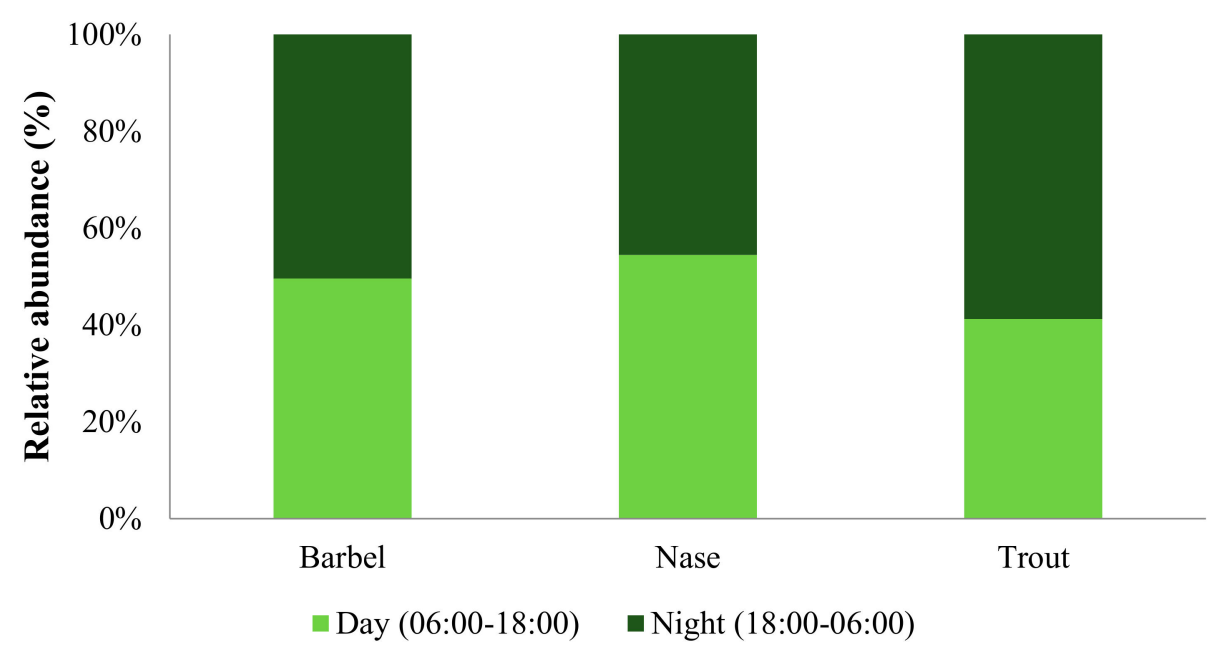

Figure 3. Abundance of barbel, nase and trout recorded in the fish lift during the day (06:00-18:00) and night (18:00-06:00).

\subsection{Effects of Environmental Variables on Fish Passability}

Water temperature $(\mathrm{F}=22.425, p<0.001)$ and daily flow fluctuation $(\mathrm{F}=4.894, p<0.001)$ were positively associated with nase passability. The fitted model for this species included a third significant variable positively associated-photoperiod $(\mathrm{F}=3.955, p=0.049)($ Table 1$)$. Water temperature was also included in the model for barbel passability $(\mathrm{F}=7.138, p=0.008)$, together with mean daily flow $(\mathrm{F}=7.733, p=0.006)$ and accumulated rainfall $(\mathrm{F}=12.818, p<0.001)$ as significant variables, all with positive associations (Table 1). For trout, only the mean daily flow (positively associated) was retained in the final model $(\mathrm{F}=3.941, p=0.049)$. 
Table 1. Variables entered in the GLMs explaining species abundance in the Touvedo fish lift. Seven different factors were analyzed, but only those included in the final models are presented. For each species, significance of each variable in the final model was calculated through the F-test. Beta coefficients (B) and Durbin-Watson statistics (D) for each model are also presented.

\begin{tabular}{ccccc}
\hline Variable & $\boldsymbol{B}$ & $\boldsymbol{F}$-Test & $p$-Value & $\boldsymbol{D}$ \\
\hline P. duriense & & & & 1.127 \\
Water temperature & 0.466 & 22.425 & $<0.001$ & \\
Flow variation & 0.228 & 4.894 & 0.029 & \\
Photoperiod & 0.198 & 3.955 & 0.049 & 1.812 \\
$\quad$ L. bocagei & & & & \\
Water temperature & 0.167 & 7.138 & 0.008 & \\
Mean daily flow & 0.155 & 7.733 & 0.006 & \\
Acumulated rainfall & 0.276 & 12.818 & $<0.001$ & \multirow{2}{*}{0.996} \\
S. trutta fario & & & & \\
Mean daily flow & 0.151 & 3.941 & 0.049 & \\
\hline
\end{tabular}

\subsection{Fish Passage in Relation to Peak-Flow Magnitudes}

Fish lift use varied according to peak-flow magnitudes, with nase showing significant differences in passability $\left(\chi^{2}=55.460, \mathrm{df}=2, p<0.001\right)$. Accordingly, passability of this species was the highest $(67.8 \%)$ when the powerhouse was off $\left(0 \mathrm{~m}^{3} \mathrm{~s}^{-1}\right.$, Figure 4$)$. Contrastingly, passability of larger species, i.e., barbel $\left(\chi^{2}=6.480, \mathrm{df}=2, p=0.039\right)$ and trout $\left(\chi^{2}=5.631, \mathrm{df}=2, p=0.060\right)$ occurred mainly when the powerhouse was operating, being the highest for the barbel (44.8\%) upon operation at half-load $\left(50 \mathrm{~m}^{3} \mathrm{~s}^{-1}\right)$, whereas for the trout, the largest portion of individuals (44.2\%) migrating occurred when the powerhouse was operating at full-load, though differences in the last species were not significant $\left(100 \mathrm{~m}^{3} \mathrm{~s}^{-1} ; \chi^{2}=5.631, \mathrm{df}=2, p=0.060\right)$.

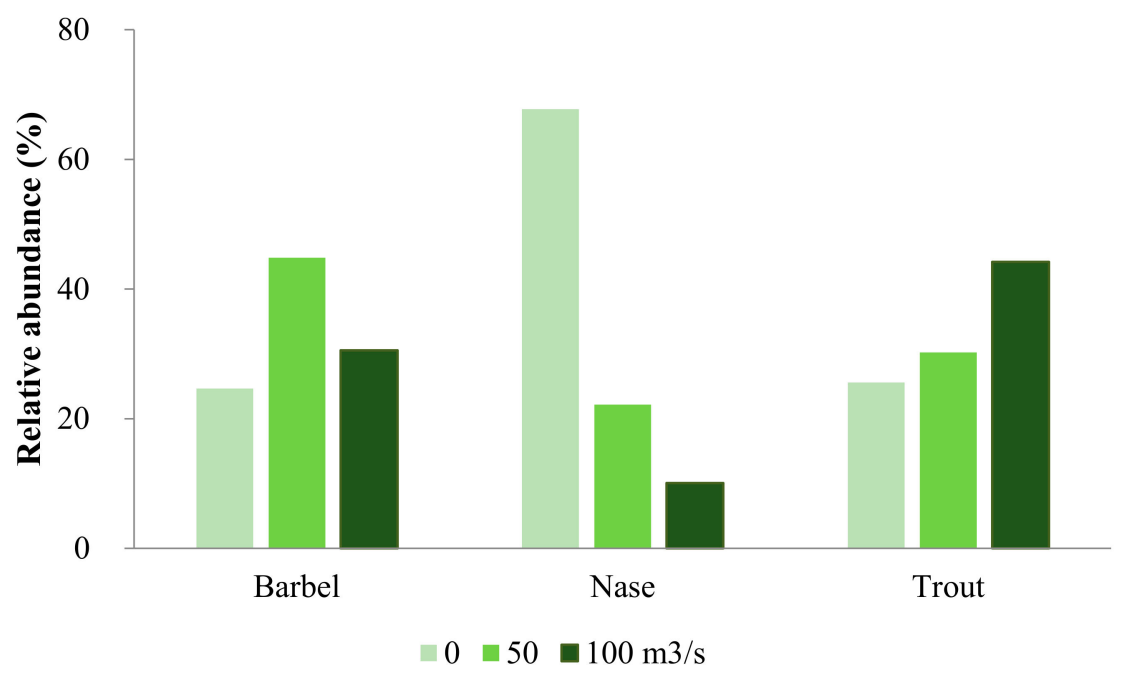

Figure 4. Relative abundance (\%) of barbel, nase and trout recorded in the lift for different peak-flow magnitudes: $0 \mathrm{~m}^{3} \mathrm{~s}^{-1}$ (pale green; powerhouse off), $50 \mathrm{~m}^{3} \mathrm{~s}^{-1}$ (light green; powerhouse at half-load) and $100 \mathrm{~m}^{3} \mathrm{~s}^{-1}$ (dark green; powerhouse at full-load).

\subsection{Fish Lift Selectivity}

Differences in population size structure were found when comparing the proportions of fish counts in the lift and captures downstream of the Touvedo dam for all three species (Fisher's exact test, $p<0.05$ ), though these differences were more pronounced in barbel and trout (Fisher's exact test, $p<0.001$ ), with some selectiveness being observed (Figure 5). For both species, the proportions of individuals observed in the lift (barbel: mean $\pm \mathrm{SD}=22.4 \pm 6.9 \mathrm{~cm}$; trout: $23.5 \pm 4.2 \mathrm{~cm}$ ) were generally larger than the ones captured in the river segment downstream (barbel: $18.1 \pm 4.5$; trout: $16.5 \pm 4.5 \mathrm{~cm}$ ). 
Nonetheless, for barbel, both lift recordings and river surveys revealed $15-20 \mathrm{~cm}$ individuals as the most abundant size class (Figure 5). For nase, despite differences in size-class distributions were found (Fisher's exact test, $p=0.016$; mean size $\pm \mathrm{SD}=13.0 \pm 3.6$ in the lift and $13.3 \pm 2.9$ in caught fish), the same size classes were represented in the lift and river surveys, but with a larger proportion of the smallest size individuals ( $\mathrm{TL} \leq 10 \mathrm{~cm})$ occurring in the fish lift: $24.3 \%(10.1 \%$ in the river downstream) (Figure 5).

\section{Barbel}

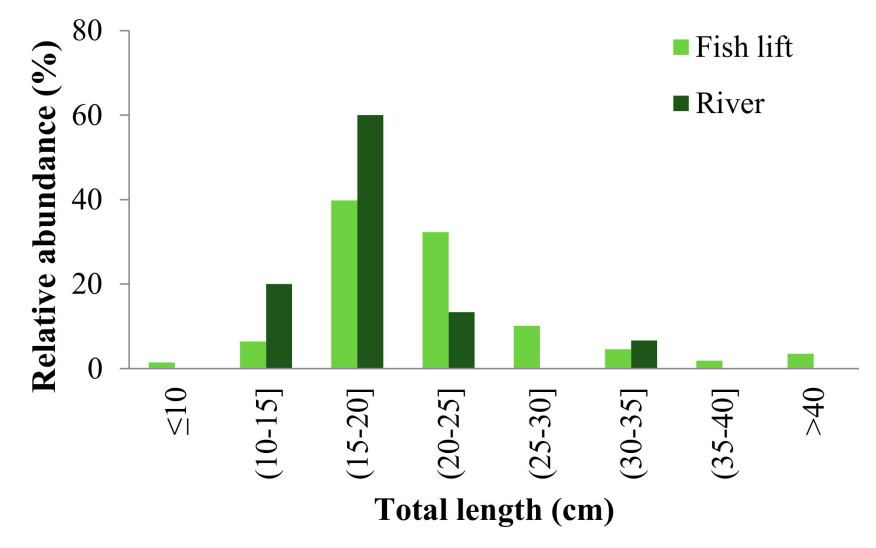

Nase

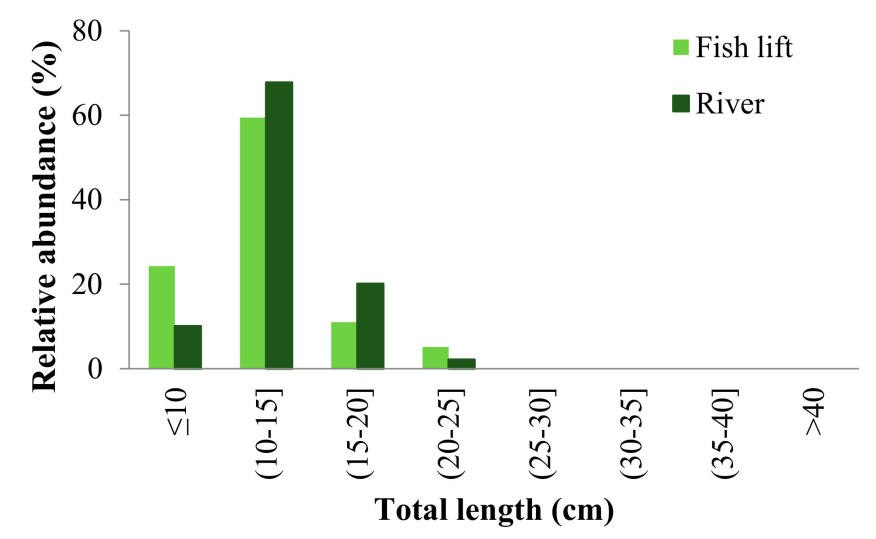

Trout

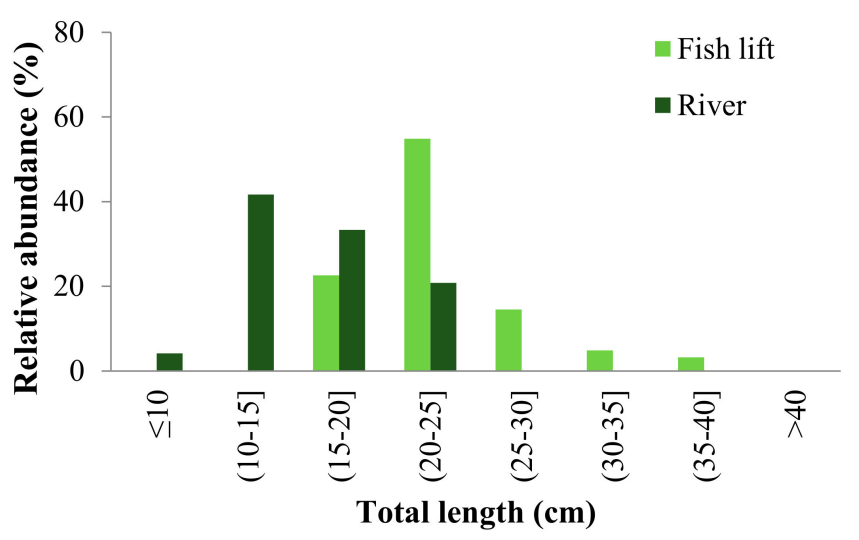

Figure 5. Size class (cm) distributions of barbel, nase and trout recorded in the lift (light green) and captured downstream of the Touvedo dam (dark green). 


\subsection{Fish Lift Efficacy}

The passage-to-catch ratio was generally higher in barbel (mean $\pm \mathrm{SD}=1.36 \pm 1.06$ ) than in nase (mean $\pm \mathrm{SD}=0.26 \pm 0.25$ ) and trout (mean $\pm \mathrm{SD}=0.10 \pm 0.10$ ). Average monthly ratios for the barbel were superior to the unit in half of the study period, attaining a maximum value of 3.10 in September (Table 2), when this species recorded higher counts in the lift (Figure 2). Ratios for nase in its most active period (August-October; Figure 2) varied between 0.43 and 0.75 , being considerably higher than the ratios obtained in the remaining months $(\leq 0.10$; Table 2$)$. For trout, ratios were generally low throughout the year, despite an increase was observed in September-October, when mean values were superior to the overall mean obtained for this species $(0.10)$.

Table 2. Mean daily number of barbel, nase and trout migrating through the Touvedo fish lift and captured downstream by electrofishing in 2013 (unit effort = 1 fishing day ( $4 \mathrm{~h}$ of effective sampling)), along with ratios of fish-lift records to downstream catches. (a) Undetermined ratio due to the absence of caught individuals by electrofishing, despite being observed in the fish lift.

\begin{tabular}{|c|c|c|c|c|c|c|c|c|c|}
\hline \multirow[b]{2}{*}{ Month } & \multicolumn{3}{|c|}{ Barbel } & \multicolumn{3}{|c|}{ Nase } & \multicolumn{3}{|c|}{ Trout } \\
\hline & $\begin{array}{l}\text { Fish Lift } \\
\text { N Day }\end{array}$ & $\begin{array}{c}\text { Electr. Catch } \\
\text { N Unit Effort }{ }^{-1}\end{array}$ & Ratio & $\begin{array}{l}\text { Fish Lift } \\
\text { N Day }^{-1}\end{array}$ & $\begin{array}{c}\text { Electr. Catch } \\
\text { N Unit Effort }{ }^{-1}\end{array}$ & Ratio & $\begin{array}{l}\text { Fish Lift } \\
\text { N Day }^{-1}\end{array}$ & $\begin{array}{c}\text { Electr. Catch } \\
\text { N Unit Effort } \\
-1\end{array}$ & Ratio \\
\hline May & 1.52 & 0 & (a) & 0.42 & 1 & 0.42 & 0.16 & 0 & (a) \\
\hline Jun & 1.36 & 2 & 0.68 & 0.50 & 18 & 0.03 & 0.03 & 1 & 0.03 \\
\hline Jul & 0.77 & 0 & (a) & 1.26 & 13 & 0.10 & 0.06 & 1 & 0.06 \\
\hline Oct & 4.03 & 12 & 0.34 & 4.03 & 34 & 0.47 & 0.35 & 1 & 0.35 \\
\hline Nov & 1.34 & 1 & 1.30 & 1.34 & 28 & 0.09 & 0.14 & 2 & 0.07 \\
\hline Dec & 0.62 & 0 & (a) & 0.62 & 29 & 0.03 & 0.10 & 9 & 0.01 \\
\hline Mean & 1.82 & 1.78 & 1.36 & 5.04 & 21.00 & 0.26 & 0.20 & 2.67 & 0.10 \\
\hline
\end{tabular}

\section{Discussion}

This study assessed the effectiveness with which a fish lift in a LHP allows native potamodromous fish to migrate upstream. To accomplish such goal, we assessed the seasonal and daily use of the lift by fish and compared it with the environmental factors that are known to be associated with the triggering of the fish upstream migration, the peak-flow magnitudes at the power plant and the size structure and abundance of the fish population downstream. This continuous monitoring of fish stocks downstream the dam, though time-consuming and enclosing inherent technical difficulties of sampling a large river [51], has seldom been used in fish lift evaluation studies (e.g., [23,30]) and provided a useful proxy of the efficacy of the fish lift that, together with the seasonality of fish movements, can be used by managers to better plan fish lift operations and shutdowns.

As it was expected, fish counts through the lift varied significantly between the different months for all three species. Overall, the highest number of fish counts was attained in late summer-early fall, when almost $80 \%$ of the individuals used the fish lift, with nase being the most abundant species (74.7\% of the total fish counts), followed by barbel (22.7\%). The large proportions of both species observed in late summer is consistent with previous reports on these rheophilic cyprinids $[52,53]$. Similarly, in a work by De Leeuw and Winter [53] in the lowland rivers Meuse and Rhine in the Netherlands, the authors reported more movements of the common barbel Barbus barbus and common nase Chondrostoma nasus during both summer-early fall (July-October) and spring (spawning season for both species). It is highly likely that such activity observed in the lift is related to reproductive migrations, which takes place during these periods, particularly in summer [40,41], when these potamodromous species migrate upstream to seek areas for reproduction, typically in gravel and pebble beds located in upstream tributaries [39]. These species also showed movements outside their usual spawning period, displaying a second peak in early-fall (September-October), a result that is also consistent with other studies, in which "out of season" movements may reflect a search for winter, feeding or thermal refuges, as it has been observed in other potamodromous cyprinids [15,54]. 
The presence of trout in the fish lift was residual (only $2.6 \%$ of the total fish counts), with movements occurring throughout the year and not only restricted to the spawning period, which typically occurs during late fall and winter [43]. The similarity of observed seasonal fish counts in the lift, with the species migratory ecology, provides therefore an indication that the lift is not disrupting the seasonality of fish movements, serving therefore its purpose.

No significant differences were found in daily patterns of fish passage ascending the fish lift, which is in accordance with our expectations. Though some studies suggest that cyprinids are more active during the night to avoid predation (e.g., [37,41]), such patterns can be quite species-specific [16]. In a recent study conducted in the Meuse river basin (Belgium), Benitez et al. [16] found that the common barbel Barbus barbus did not show any differences in daily activity when passing through the existing fishways, contrarily to the trout, which was more active during the day, a result that was also supported by some authors (e.g., [43]), but not others (e.g., [42]). In a series of surveys conducted in the Zêzere River (Tagus river basin), Santos et al. [52] also did not find differences in daily activity for the Iberian straight-mouth nase (Pseudochondrosoma polylepis), a sister species of the present P. duriense. Such findings, as well those of the present study, reflect the absence of predators in the sampled river segment downstream of the Touvedo dam [44], which does not constrain the activity of native species to take place during night-time periods when survival would be expected to be maximum $[26,41]$.

Water temperature was found to be the most significant predictor of the abundance of both cyprinids (barbel and nase), which is consistent with our expectations and with previous findings on the migratory ecology of these species, where increasing water temperature acts as an environmental trigger for the upstream movements of these species [30,55]. Flow variables (mean daily flow and daily flow fluctuations) were also important to explain upstream movements of both cyprinids, as it was previously expected: daily flow fluctuation, which can act as an environmental trigger for fish migration $[45,56]$, also had a positive effect on the observed nase in the lift, whereas barbel abundance in the fish lift was positively associated with increasing mean daily flow. Moreover, accumulated rainfall, which also has a direct influence in river flow [57], was also present in the model for barbel passability. Taken together, these results corroborate the ones in the literature in which flow (in addition to water temperature) is also one of the most important variables in triggering fish migration $[45,58]$, particularly under conditions of high-water level fluctuation [59] as in the Touvedo LHP. Photoperiod was also positively associated with barbel passability, which seems to indicate a higher activity during the day in the lack of predators [60], as previously mentioned. Mean daily flow was the only variable selected by the model to explain the number of trout individuals that migrated through the fish lift. This result is in agreement with some studies [61,62], but not with others $[30,41]$ that pointed out water temperature as the most important factor in the upstream migration of this species. It should be noted, however, that the number of individuals recorded was considerably lower compared to the remaining potamodromous species, which may have reduced the statistical power of our analyses. On the other hand, it is possible that a different hierarchy of environmental factors stimulated the same behaviour in different years [45]. Hence, long-term studies could provide a broader understanding of the interaction between environmental variability and potamodromous fish movements, in order to clarify trends over long time series ( $>10$ years), while also providing important data for scientists and ecosystem managers.

Fish passage in relation to the different peak-flow magnitudes differed in two of the three species, with the largest proportion of nase $(67.8 \%$ of total abundance) using the fish lift in the absence of turbined flow (powerhouse off). Contrarily, barbel made broader use of the fish lift when the powerhouse was operating at half-load $\left(50 \mathrm{~m}^{3} \mathrm{~s}^{-1}\right)$. As for trout, it should be noted that while differences were not significant, the largest proportion of movements occurred when the powerhouse was operating at full-load $\left(100 \mathrm{~m}^{3} \mathrm{~s}^{-1}\right)$. It is our conviction that nase made larger use of the fish lift when the powerhouse was off (i.e., with turbines shutdown) due to the lower water velocities (0.21-0.55 $\left.\mathrm{m} \mathrm{s}^{-1}\right)$ that occur at the lift entrances upon this scenario [44]. Though nase is a medium-sized cyprinid [63], for which adults can cope critical swimming speeds up to $0.78 \mathrm{~m} \mathrm{~s}^{-1}$ [64] and therefore 
theoretically being able to negotiate such a range of velocities, individuals found in both river segment downstream and lift were mainly juveniles, small-sized fish (mean: $13.0 \mathrm{~cm}$ TL), for which swimming performance is typically lower than larger conspecifics $[65,66]$. It is thus important to ensure that water velocities that nase will face within the entrances that lead to the lift are sufficiently attractive-not too low $\left(<0.20 \mathrm{~m} \mathrm{~s}^{-1}\right)$ to hinder attraction [29], nor too high, above their critical swimming speed $\left(>0.78 \mathrm{~m} \mathrm{~s}^{-1},[64]\right)$ - for appropriate entrance and passage, particularly during summer and early fall when most of the individuals $(74.7 \%)$ used the fish lift. It is tempting to suggest that managers should try to implement management strategies, such as periodic turbine shutdown [67], that best balance the trade-off between energy production and the potential for upstream fish migration [68], at least during the critical migratory periods. However, this is often difficult to achieve and dependent on the characteristics of the national network of hydropower schemes as well as on the specificities of the energy market. Nevertheless, the specific requirements of the different species migrating, namely swimming performance, should be taken into account when planning for a mitigation flow scheme such as ecological flow releases. Both barbel (mean TL: $22.4 \mathrm{~cm}$ ) and trout (mean TL: $23.5 \mathrm{~cm}$ ), the two largest species that used the lift, have rheophilic habits during part (barbel) or the whole (trout) life-cycle [36], which, combined with their greater ability to withstand higher velocities during short time periods (adult barbel: $U_{\text {crit }}=0.81 \mathrm{~m} \mathrm{~s}^{-1}$, [69]; trout: $U_{c r i t}=0.65 \mathrm{~m} \mathrm{~s}^{-1}$ and $U_{\text {max }}$ varying between 0.94-1.26 $\mathrm{m} \mathrm{s}^{-1}$, depending on water temperature, [70]), may have determined the larger proportion of individuals of both species using the fish lift under the half- load $\left(50 \mathrm{~m}^{3} \mathrm{~s}^{-1}\right)$ and full-load $\left(100 \mathrm{~m}^{3} \mathrm{~s}^{-1}\right)$ conditions, respectively. It should be noted, however, that the willingness to enter and use the fish lift cannot be explained solely by the water velocity at the entrances nor the size of individuals. Such motivation can also be driven by other internal (such as the physiological condition or fatigue level) or external (such as turbidity or turbulence) factors not accounted for in the present study. For example, some recent studies on fish passage have pointed out the importance of turbulence in determining the success and timing of potamodromous fish migration upstream [71,72]. It is clear that future studies should focus on experimental controlled conditions, where the variables of interest (e.g., water velocity and associated turbulence parameters) can be manipulated while controlling for potential confounding factors (e.g., temperature), which provide an excellent opportunity to disentangle the effect that multiple factors have on fish attraction and passage through fish lifts.

The comparison of species size-structure between observed fish in the lift and those captured downstream, which gives an indicator of fishway selectivity, showed some differences for all three species, particularly for barbel and trout, with the occurrence of larger individuals in the fish lift relatively to the river downstream, as it was previously predicted (see Introduction). Such selectivity could have also arisen as a result of sampling the fish with electrofishing in specific habitats, such as deep pools, where typically the larger fish, like barbel and trout [44], dwell, and where capture efficiency is often lower than in shallower (up to $1.5 \mathrm{~m}$ ) habitats $[9,63]$. On the other hand, the smaller individuals of these species may not display a marked migration stimulus, at least associated with reproduction (e.g., [15]), so their abundance in the fish lift should be lower than that of the larger ones. Another relevant aspect that could partially explain the lower abundance of smaller-sized individuals of these species is related to the potential effect of water velocity in the fish lift attraction circuit (up to $0.90 \mathrm{~m} \mathrm{~s}^{-1}$ when the powerhouse is on), which may have limited the entrance of smaller individuals, for which swimming capacity is typically more limited comparatively to the larger ones [66]. Assessing their swimming capabilities would help clarify if the observed patterns are related with their lower swimming capabilities, or the lack of environmental cues for these smaller fish to perform upstream migrations.

As a proxy of the fish lift's efficacy, the standardized passage-to catch ratio was used, as there are presently, to the best of our knowledge, no standard methods nor metrics to evaluate efficacy, neither any defined thresholds (e.g., [46,73]). Our results showed that the mean value of this indicator was higher than 1 for the barbel, suggesting that more individuals were using the fish lift compared to those that were available downstream and captured by electrofishing. As outlined above, such results should 
be analyzed with caution as most barbel, particularly the larger individuals, often dwell in deep pool habitats [9] where electrofishing is clearly less effective [74], and thus their population downstream that is potentially available to migrate could have been under-evaluated. The use of other techniques, such as mark-recapture or passive integrated transponders (PIT) telemetry [75], can be useful to provide more accurate data on barbel stocks arriving at the foot of large-scale barriers. The mean ratio obtained for the nase (0.26), the most abundant species in the fish lift, was higher than those reported by Noonan et al. [26], who reviewed worldwide estimates of fish passage efficiency across all types of fishways. In the case of fish lifts and the presence of non-salmonid species, the mean value reported was only 0.10 , which makes the present estimate $(0.26)$ quite optimistic in the current context, although their work focuses on efficiency rather than efficacy as in the present study. However, since the concept of efficacy is not defined in terms of minimum standards (e.g., [41,46]), it should be specified with respect to the biological requirements of the species using the fishway, and not as an absolute value [47]. In the Lima basin, cyprinids are the most dominant and abundant species in the main river $[9,41]$. Consequently, the main goal of the lift, rather than allowing the whole species' population downstream to move upstream the dam (as it would in the case of anadromous or catadromous species), is to prevent fragmentation of potamodromous populations between different river segments [25]. For such species that carry out their life cycles downstream and upstream the dam [30], simple documentation of them passing upstream is sufficient [76], providing enough evidence that a considerable proportion of individuals used the fish lift, assuring a long-term sustainability of fish populations.

It should also be noted that the low ratios observed in the months outside the migratory season (for barbel, nase and trout) do not necessarily represent low lift efficacy, as they may reflect the absence of migratory stimuli and the consequent lack of motivation to overcome the obstacle. Trout was the species that theoretically performed the lowest, as shown by their lowest mean ratio $(0.10)$ when compared to the other two species, as well to the corresponding mean value $(0.35)$ in the literature for salmonids using fish lifts [26]. This is unlikely to reflect a lower performance of trout upon negotiating water velocities to enter the lift, as trouts are typically better swimmers and withstand higher velocities than cyprinids, but instead their natural low abundance in the present cyprinid-type river segment [77]. Future studies should try to associate efficacy to other indicators, namely efficiency and delay, to achieve a broader assessment of fish passage through a fishway [78]. In the particular case of fish lifts, it would be important to try to quantify the two components of attraction efficiency [17]: guidance (i.e., arrival at the entrance) in response to attraction currents, and entry (i.e., decision to enter). In this sense, biotelemetry techniques could be applied to monitor such fine-scale activity.

Finally, it should be pointed out that actions to improve the efficacy of upstream movements of potamodromous species at fish lifts may not always be the best practice. Fish lifts are unidirectional systems, transporting fish from downstream to upstream of dams, but do not operate on the reverse side (i.e., from upstream to downstream), therefore not allowing subsequent downstream migration. When this is coupled with the absence of suitable spawning and growth habitats upstream (even if they are present downstream), fish lifts may act as ecological traps, doing more harm than good to fish populations [79]. Although a unidirectional fishway, the Touvedo fish lift is not likely to be acting as an ecological trap, due to the existence of a network of good quality habitats upstream the Touvedo dam (see Study Area). Taken together, the Touvedo fish lift enables the upstream migration of a "considerable" number of adult potamodromous fish in the proper seasonal timing, which is a positive step towards the maintenance of populations above and below the dam, potentially contributing to their future sustainability. However, different fish species were found to be affected differently by the peak-flow magnitudes (nase preferentially migrating during periods of turbine shutdown, whereas barbel and trout making broader use of the lift when the powerhouse was operating), which points to the need of a proper peak-flow management during the species reproductive season. Future studies should consider determining to what extent fish can safely use the spillway gates or the turbines as a pathway in their descendent routes. 
Author Contributions: Conceptualization, J.P., M.T.F. and J.M.S.; methodology, D.M., R.R., J.M.O., J.P. and J.M.S.; formal analysis, D.M. and J.M.S.; investigation, D.M. and J.M.S., writing—original draft preparation: D.M. and J.M.S.; writing-review and editing, R.R., J.M.O., J.P. and M.T.F.; supervision, M.T.F. and J.M.S. All authors have read and agreed to the published version of the manuscript.

Funding: Forest Research Centre (CEF) is a research unit funded by Fundação para a Ciência e a Tecnologia I.P. (FCT), Portugal (UID/AGR/00239/2019). This study was supported by EDP, S.A. (Energias de Portugal), who allowed the use of their facilities and equipment (video recording system). The funders had no role in study design, data collection and analysis, decision to publish, or preparation of the manuscript. Daniel Mameri is supported by a Ph.D. grant from the FLUVIO-River Restoration and Management programme funded by FCT (PD/BD/142885/2018). José Maria Santos is presently the recipient of a FCT researcher contract (IF/00020/2015).

Acknowledgments: The authors wish to thank Raul Arenas, Paulo Branco and André Fabião for their help during the electrofishing sampling campaigns. Thanks are also due Ulisses Cabral and António Leite Marinho for assistance, field and video logistics. The Institute for Nature Conservation and Forests (ICNF) provided the necessary fishing and handling permits. Finally, the authors want to thank the comments and suggestions from three anonymous reviewers, who greatly improved an early version of this manuscript.

Conflicts of Interest: The authors declare no conflict of interest.

\section{References}

1. Dudgeon, D.; Arthington, A.H.; Gessner, M.O.; Kawabata, Z.I.; Knowler, D.J.; Lévêque, C.; Naiman, R.J.; Prieur-Richard, A.H.; Soto, D.; Stiassny, M.L.J.; et al. Freshwater biodiversity: Importance, threats, status and conservation challenges. Biol. Rev. 2005, 81, 163-182. [CrossRef] [PubMed]

2. Vörösmarty, C.J.; McIntyre, P.B.; Gessner, M.O.; Dudgeon, D.; Prusevich, A.; Green, P.; Glidden, S.; Bunn, S.E.; Sullivan, C.; Liermann, C.R.A.; et al. Global threats to human water security and river biodiversity. Nature 2010, 467, 555-561. [CrossRef] [PubMed]

3. Branco, P.; Segurado, P.; Santos, J.M.; Pinheiro, P.; Ferreira, M.T. Does longitudinal connectivity loss affect the distribution of freshwater fish? Ecol. Eng. 2012, 48, 70-78. [CrossRef]

4. Fullerton, A.H.; Burnett, K.M.; Steel, E.A.; Flitcroft, R.L.; Pess, G.R.; Feist, B.E.; Torgersen, C.E.; Miller, D.J.; Sanderson, B.L. Hydrological connectivity for riverine fish: Measurement challenges and research opportunities. Freshw. Biol. 2010, 55, 2215-2237. [CrossRef]

5. Maceda-Veiga, A. Towards the conservation of freshwater fish: Iberian Rivers as an example of threats and management practices. Rev. Fish Biol. Fish. 2012, 23, 1-22. [CrossRef]

6. Boavida, I.; Santos, J.M.; Ferreira, T.; Pinheiro, A. Barbel habitat alterations due to hydropeaking. J. Hydro-Environ. Res. 2015, 9, 237-247. [CrossRef]

7. Hayes, D.; Moreira, M.; Boavida, I.; Haslauer, M.; Unfer, G.; Zeiringer, B.; Greimel, F.; Auer, S.; Ferreira, T.; Schmutz, S. Life Stage-Specific Hydropeaking Flow Rules. Sustainability 2019, 11, 1547. [CrossRef]

8. Oliveira, J.M.; Ferreira, M.T.; Pinheiro, A.N.; Bochechas, J.H. A simple method for assessing minimum flows in regulated rivers: The case of sea lamprey reproduction. Aquat. Conserv. 2004, 14, 481-489. [CrossRef]

9. Santos, J.M.; Godinho, F.; Ferreira, M.T.; Cortes, R. The organisation of fish assemblages in the regulated Lima basin, Northern Portugal. Limnologica 2004, 34, 224-235. [CrossRef]

10. Bruder, A.; Tonolla, D.; Schweizer, S.P.; Vollenweider, S.; Langhans, S.D.; Wüest, A. A conceptual framework for hydropeaking mitigation. Sci. Total Environ. 2016, 568, 1204-1212. [CrossRef]

11. Capra, H.; Plichard, L.; Bergé, J.; Pella, H.; Ovidio, M.; McNeil, E.; Lamouroux, N. Fish habitat selection in a large hydropeaking river: Strong individual and temporal variations revealed by telemetry. Sci. Total Environ. 2017, 578, 109-120. [CrossRef] [PubMed]

12. Enders, E.C.; Watkinson, D.A.; Ghamry, H.; Mills, K.H.; Franzin, W.G. Fish age and size distributions and species composition in a large, hydropeaking Prairie River. River Res. Appl. 2017, 33, 1246-1256. [CrossRef]

13. Schmutz, S.; Bakken, T.H.; Friedrich, T.; Greimel, F.; Harby, A.; Jungwirth, M.; Melcher, A.; Unfer, G.; Zeiringer, B. Response of Fish Communities to Hydrological and Morphological Alterations in Hydropeaking Rivers of Austria. River Res. Appl. 2014, 31, 919-930. [CrossRef]

14. Baras, E.; Lucas, M. Impacts of man's modifications of river hydrology on the migration of freshwater fishes: A mechanistic perspective. Ecohydrol. Hydrobiol. 2001, 1, 291-304.

15. Benitez, J.P.; Matondo, B.N.; Dierckx, A.; Ovidio, M. An overview of potamodromous fish upstream movements in medium-sized rivers, by means of fish passes monitoring. Aquat. Ecol. 2015, 49, 481-497. [CrossRef] 
16. Benitez, J.P.; Dierckx, A.; Matondo, B.N.; Rollin, X.; Ovidio, M. Movement behaviours of potamodromous fish within a large anthropised river after the reestablishment of the longitudinal connectivity. Fish. Res. 2018, 207, 140-149. [CrossRef]

17. Roscoe, D.W.; Hinch, S.G. Effectiveness monitoring of fish passage facilities: Historical trends, geographic patterns and future directions. Fish Fish. 2010, 11, 12-33. [CrossRef]

18. Clay, C.H. Design of Fishways and Other Fish Facilities, 2nd ed.; Lewis Publishers: Boca Raton, FL, USA, 1995; 256p.

19. Food and Agriculture Organization (FAO); Deutsche Vereinigung für Wasserwirtschaft, Abwasser und Abfall (DVWK). Fish Passes_Design, Dimensions and Monitoring; FAO: Rome, Italy, 2002; 119p.

20. Santos, J.M.; Silva, A.; Katopodis, C.; Pinheiro, P.; Pinheiro, A.; Bochechas, J.; Ferreira, M.T. Ecohydraulics of pool-type fishways: Getting past the barriers. Ecol. Eng. 2012, 48, 38-50. [CrossRef]

21. Larinier, M. Biological factors to be taken into account in the design of fishways, the concept of obstruction to upstream migration. Bull. Fr. Pêche Piscic. 2002, 364, 28-38. [CrossRef]

22. Allan, J.D.; Castillo, M.M. Stream Ecology-Structure and Function of Running Waters; Springer: Dordrecht, The Netherlands, 2007; 436p. [CrossRef]

23. Croze, O.; Bau, F.; Delmouly, L. Efficiency of a fish lift for returning Atlantic salmon at a large-scale hydroelectric complex in France. Fish. Manag. Ecol. 2008, 15, 467-476. [CrossRef]

24. Schletterer, M.; Reindl, R.; Thonhauser, S. Options for re-establishing river continuity, with an emphasis on the special solution "fish lift": Examples from Austria. Rev. Eletrônica Gestão Tecnol. Ambient. 2016, 4, 109. [CrossRef]

25. Travade, F.; Larinier, M. Fish locks and fish lifts. Bull. Fr. Pêche Piscic. 2002, 364, 102-118. [CrossRef]

26. Noonan, M.J.; Grant, J.W.A.; Jackson, C.D. A quantitative assessment of fish passage efficiency. Fish Fish. 2011, 13, 450-464. [CrossRef]

27. Pompeu, P.D.S.; Martinez, C.B. Efficiency and selectivity of a trap and truck fish passage system in Brazil. Neotrop. Ichthyol. 2007, 5, 169-176. [CrossRef]

28. Larinier, M.; Chanseau, M.; Bau, F.; Croze, O. The use of radio telemetry for optimizing fish pass design. In Aquatic Telemetry: Advances and Applications, Proceedings of the Fifth Conference on Fish Telemetry held in Ustica, Italy, 9-13 June 2003; FAO/COISPA: Rome, Italy, 2005.

29. Santos, J.M.; Rivaes, R.; Oliveira, J.; Ferreira, T. Improving yellow eel upstream movements with fish lifts. J. Ecohydraulics 2016, 1, 50-61. [CrossRef]

30. Santos, J.M.; Ferreira, M.T.; Godinho, F.N.; Bochechas, J. Performance of fish lift recently built at the Touvedo Dam on the Lima River, Portugal. J. Appl. Ichthyol. 2002, 18, 118-123. [CrossRef]

31. Morán-López, R.; Uceda Tolosa, O. Image techniques in turbid rivers: A ten-year assessment of cyprinid stocks composition and size. Fish. Res. 2017, 195, 186-193. [CrossRef]

32. Benitez, J.P.; Ovidio, M. The influence of environmental factors on the upstream movements of rheophilic cyprinids according to their position in a river basin. Ecol. Freshw. Fish 2017, 27, 660-671. [CrossRef]

33. Katopodis, C.; Williams, J.G. The development of fish passage research in a historical context. Ecol. Eng. 2012, 48, 8-18. [CrossRef]

34. Nieminen, E.; Hyytiäinen, K.; Lindroos, M. Economic and policy considerations regarding hydropower and migratory fish. Fish Fish. 2016, 18, 54-78. [CrossRef]

35. Boavida, I.; Jesus, J.B.; Pereira, V.; Santos, C.; Lopes, M.; Cortes, R.M.V. Fulfilling spawning flow requirements for potamodromous cyprinids in a restored river segment. Sci. Total Environ. 2018, 635, 567-575. [CrossRef] [PubMed]

36. Ferreira, M.T.; Sousa, L.; Santos, J.M.; Reino, L.; Oliveira, J.; Almeida, P.R.; Cortes, R.V. Regional and local environmental correlates of native Iberian fish fauna. Ecol. Freshw. Fish 2007, 16, 504-514. [CrossRef]

37. Lucas, M.C.; Mercer, T.; Peirson, G.; Frear, P.A. Seasonal movements of coarse fish in lowland rivers and their relevance to fisheries management. In Management and Ecology of River Fisheries; Cowx, I.G., Ed.; Fishing New Books: Oxford, UK, 2000; pp. 87-100.

38. Lucas, M.C.; Frear, P.A. Effects of a flow-gauging weir on the migratory behaviour of adult barbel, a riverine cyprinid. J. Fish Biol. 1997, 50, 382-396. [CrossRef]

39. Doadrio, I.; Perea, S.; Garzón-Heydt, P.; González, J.L. Ictiofauna Continental Española. Bases Para Su Seguimiento; D.G. Medio Natural y Política Forestal; MARM: Madrid, Spain, 2011;616p. 
40. Rodriguez-Ruiz, A.; Granado-Lorencio, C. Spawning period and migration of three species of cyprinids in a stream with Mediterranean regimen (SW Spain). J. Fish Biol. 1992, 41, 545-556. [CrossRef]

41. Santos, J.M.; Ferreira, M.T.; Godinho, F.N.; Bochechas, J. Efficacy of a nature-like bypass channel in a Portuguese lowland river. J. Appl. Ichthyol. 2005, 21, 381-388. [CrossRef]

42. Ovidio, M.; Baras, E.; Goffaux, D.; Giroux, F.; Philippart, J.C. Seasonal variations of activity pattern of brown (Salmo trutta) in a small stream, as determined by radio-telemetry. Hydrobiologia 2002, 470, 195-202. [CrossRef]

43. García-Vega, A.; Sanz-Ronda, F.J.; Fuentes-Pérez, J.F. Seasonal and daily upstream movements of brown trout Salmo trutta in an Iberian regulated river. Knowl. Manag. Aquat. Ecosyst. 2017, 418, 9. [CrossRef]

44. Santos, J.M.; Oliveira, J.M.; Rivaes, R.; Pizarro, R.A.; Ferreira, M.T.; Pádua, J.; Marin, C. Plano de Ação para a Otimização do Ascensor de Peixes do Aproveitamento Hidroelétrico de Touvedo; Relatório Final; Instituto Superior de Agronomia da Universidade de Lisboa e EDP Labelec: Lisboa, Portugal, 2014; 142p.

45. Jonsson, N. Influence of water flow, water temperature and light on fish migration in rivers. Nordic J. Freshw. Res. 1991, 66, 20-35.

46. Bunt, C.M.; Castro-Santos, T.; Haro, A. Performance of fish passage structures at upstream barriers to migration. River Res. Appl. 2012, 28, 457-478. [CrossRef]

47. Larinier, M. Fish passage experience at small-scale hydro-electric power plants in France. Hydrobiologia 2008, 609, 97-108. [CrossRef]

48. Laine, A.; Jokivirta, T.; Katopodis, C. Atlantic salmon, Salmo salar L., and sea trout, Salmo trutta L., passage in a regulated northern river-Fishway efficiency, fish entrance and environmental factors. Fish. Manag. Ecol. 2002, 9, 65-77. [CrossRef]

49. R Core Team. R: A Language and Environment for Statistical Computing; R Foundation for Statistical Computing: Vienna, Austria, 2018.

50. Venables, W.N.; Ripley, B.D. Modern Applied Statistics with S, 4th ed.; Springer: New York, NY, USA, 2002; 498p. [CrossRef]

51. Plichard, L.; Capra, H.; Mons, R.; Pella, H.; Lamouroux, N. Comparing electrofishing and snorkelling for characterizing fish assemblages over time and space. Can. J. Fish. Aquat. Sci. 2017, 74, 75-86. [CrossRef]

52. Santos, J.M.; Pinheiro, P.J.; Ferreira, M.T.; Bochechas, J. Monitoring fish passes using infrared beaming: A case study in an Iberian river. J. Appl. Ichthyol. 2008, 24, 26-30. [CrossRef]

53. De Leeuw, J.J.; Winter, H.V. Migration of rheophilic fish in the large lowland rivers Meuse and Rhine, the Netherlands. Fish. Manag. Ecol. 2008, 15, 409-415. [CrossRef]

54. Ovidio, M.; Capra, H.; Philippart, J.C. Field protocol for assessing small obstacles to migration of brown trout Salmo trutta, and European grayling Thymallus thymallus: A contribution to the management of free movement in rivers. Fish. Manag. Ecol. 2007, 14, 41-50. [CrossRef]

55. Granado-Lorencio, C. Fish species ecology in Spanish freshwater ecosystems. Limnetica 1992, 8, $255-261$.

56. Flodmark, L.E.W.; Vollestad, L.A.; Forseth, T. Performance of juvenile brown trout exposed to fluctuating water level and temperature. J. Fish Biol. 2004, 65, 460-470. [CrossRef]

57. Alexandre, C.M.; Quintella, B.R.; Ferreira, A.F.; Romão, F.A.; Almeida, P.R. Swimming performance and ecomorphology of the Iberian barbel Luciobarbus bocagei (Steindachner, 1864) on permanent and temporary rivers. Ecol. Freshw. Fish 2014, 23, 244-258. [CrossRef]

58. Vilizzi, L.; Copp, G.H. An analysis of 0+ barbel (Barbus barbus) response to discharge fluctuations in a flume. River Res. Appl. 2005, 21, 421-438. [CrossRef]

59. Webb, J.; Hawkins, A.D. The movement and spawning behaviour of adult salmon in the Girnock Burn, a tributary of the Aberdeenshire Dee, 1986. In Scotish Fisheries Research Report; Department of Agriculture and Fisheries for Scotland: Edinburgh, Scotland, 1989; Volume 40, 41p.

60. Fraser, D.F.; Gilliam, J.F.; Akkara, J.T.; Albanese, B.W.; Snider, S.B. Night feeding by guppies under predator release: Effects on growth and daytime courtship. Ecology 2004, 85, 312-319. [CrossRef]

61. Lobón-Cerviá, J.; Rincón, P.A. Environmental determinants of recruitment and their influence on the population dynamics of stream-living brown trout Salmo trutta. Oikos 2004, 105, 641-646. [CrossRef]

62. Piecuch, J.; Lojkasek, B.; Lusk, S.; Marek, T. Spawning migration of brown trout, Salmo trutta in the Morávka reservoir. Folia Zool. 2007, 56, 201-212.

63. Santos, J.M.; Reino, L.; Porto, M.; Oliveira, J.; Pinheiro, P.; Almeida, P.R.; Cortes, R.; Ferreira, M.T. Complex size-dependent habitat associations in potamodromous fishspecies. Aquat. Sci. 2010, 73, 233-245. [CrossRef] 
64. Romão, F.; Quintella, B.R.; Pereira, T.J.; Almeida, P.R. Swimming performance of two Iberian cyprinids: The Tagus nase Pseudochondrostoma polylepis (Steindachner, 1864) and the bordallo Squalius carolitertii (Doadrio, 1988). J. Appl. Ichthyol. 2012, 28, 26-30. [CrossRef]

65. Plaut, I. Critical swimming speed: Its ecological relevance. Comp. Biochem. Physiol. Part A Mol. Integr. Physiol. 2001, 131, 41-50. [CrossRef]

66. Silva, A.T.; Santos, J.M.; Ferreira, M.T.; Pinheiro, A.N.; Katopodis, C. Effects of water velocity and turbulence on the behaviour of Iberian barbel (Luciobarbus bocagei, Steindachner 1864) in an experimental pool-type fishway. River Res. Appl. 2011, 27, 360-373. [CrossRef]

67. Eyler, S.M.; Welsh, S.A.; Smith, D.R.; Rockey, M.M. Downstream Passage and Impact of Turbine Shutdowns on Survival of Silver American Eels at Five Hydroelectric Dams on the Shenandoah River. Trans. Am. Fish. Soc. 2016, 145, 964-976. [CrossRef]

68. Song, C.; Omalley, A.; Roy, S.G.; Barber, B.L.; Zydlewski, J.; Mo, W. Managing dams for energy and fish tradeoffs: What does a win-win solution take? Sci. Total Environ. 2019, 669, 833-843. [CrossRef]

69. Mateus, C.S.; Quintella, B.R.; Almeida, P.R. The critical swimming speed of Iberian barbel Barbus bocagei in relation to size and sex. J. Fish Biol. 2008, 73, 1783-1789. [CrossRef]

70. Tudorache, C.; Viaene, P.; Blust, R.; Vereecken, H.; De Boek, G. A comparison of swimming capacity and energy use in seven European freshwater fish species. Ecol. Freshw. Fish 2008, 17, 284-291. [CrossRef]

71. Amaral, S.D.; Branco, P.; da Silva, A.T.; Katopodis, C.; Viseu, T.; Ferreira, M.T.; Pinheiro, A.N.; Santos, J.M. Upstream passage of potamodromous cyprinids over small weirs: The influence of key-hydraulic parameters. J. Ecohydraulics 2016, 1, 79-89. [CrossRef]

72. Amaral, S.D.; Branco, P.; Romão, F.; Viseu, T.; Ferreira, M.T.; Pinheiro, A.N.; Santos, J.M. The effect of weir crest width and discharge on passage performance of a potamodromous cyprinid. Mar. Freshw. Res. 2018, 69, 1795-1804. [CrossRef]

73. Cooke, S.J.; Hinch, S.G. Improving the reliability of fishway attraction and passage efficiency estimates to inform fishway engineering, science, and practice. Ecol. Eng. 2013, 58, 123-132. [CrossRef]

74. Teixeira-de-Mello, F.; Kristensen, E.A.; Meerhoff, M.; González-Bergonzoni, I.; Baattrup-Pedersen, A.; Iglesias, C.; Kristensen, P.B.; Mazzeo, N.; Jeppesen, E. Monitoring fish communities in wadeable lowland streams: Comparing the efficiency of electrofishing methods at contrasting fish assemblages. Environ. Monit. Assess. 2013, 186, 1665-1677. [CrossRef] [PubMed]

75. Lucas, M.C.; Baras, E. Methods for studying spatial behaviour of freshwater fishes in the natural environment. Fish Fish. 2000, 1, 283-316. [CrossRef]

76. Eberstaller, J.; Hinterhofer, M.; Parasiewicz, P. The effectiveness of two nature-like bypass channels in an upland Austrian river. In Fish Migration and Fish Bypasses; Jungwirth, M., Schmutz, S., Weiss, S., Eds.; Fishing News Books: Oxford, UK, 1998; pp. 363-383.

77. INAG-Instituto da Água. Desenvolvimento de um Indice de Qualidade para a Fauna Piscícola; Ministério da Agricultura, Mar, Ambiente e Ordenamento do Território: Lisbon, Portugal, 2012; 17p.

78. Castro-Santos, T.; Cotel, A.; Webb, P.W. Fishway evaluations for better bioengineering-An integrative approach. Am. Fish. Soc. Symp. 2009, 69, 557-575.

79. Pelicice, F.M.; Agostinho, A.A. Fish-Passage Facilities as Ecological Traps in Large Neotropical Rivers. Conserv. Biol. 2008, 22, 180-188. [CrossRef]

(C) 2019 by the authors. Licensee MDPI, Basel, Switzerland. This article is an open access article distributed under the terms and conditions of the Creative Commons Attribution (CC BY) license (http://creativecommons.org/licenses/by/4.0/). 